\title{
Shakeouts, Innovation, and Industrial Strategy and Policy
}

Kenneth L. Simons

Department of Economics, Rensselaer Polytechnic Institute

\section{Introduction}

My students of industrial organization play a game in which they manage mock companies producing the same product. Each team periodically chooses levels of investment, capacity utilization, and research spending, and keeps track of its resulting bank balances. An hour after the game begins, typically half of the companies have gone out of business and market share is spread unevenly among the few survivors.

The game mirrors a real empirical phenomenon in which, after an initial buildup in number of firms, most industries experience a drop-off or "shakeout" in the number of firms. Sometimes the shakeouts are quite dramatic: in US automobile manufacture, 98.9 per cent of producers exited between 1896, the date an automobile was first commercially produced, and 1967, shortly before Japanese entrants arrived. The top panel of Figure 1 illustrates the rise and fall in the number of US automobile producers, which rose to a peak of (by one measure) 293 firms in 1909 only to fall to 7 survivors by 1955 . $^{1}$

Empirical investigation suggests that industries with dramatic shakeouts tend to have fast-paced innovation. For example, the US automobile tire industry, which lost 95.3 per cent of its firms before 1980, experienced a shakeout beginning in 1921-22. The industry was ranked in the early 1900s as having the fastest productivity increase of any US industry. ${ }^{2}$ In automobiles, the three biggest producers were jointly responsible for 95 per cent of process innovations and 43 per cent of product innovations, and a few other early entrants made up most of the remainder. ${ }^{3}$ The substantial reductions in average cost and improvements in quality that resulted from innovation were associated with enormous increases in firm survival rates: novel-to-the-industry innovation in the preceding five years, among early entrants, was associated with an 89 per cent reduction in the annual hazard of exit. The same patterns played out, to greater or lesser degrees, in automobile tires, television receivers, and penicillin (Klepper and Simons 1997, 2000a, 2000b, 2005).

In this paper, I ask: Why do shakeouts happen, and why do a few early entrants tend to dominate innovation and survival in these industries? How general is the phenomenon of shakeouts, and the role of technological innovation in them? And finally, what does all of this suggest for strategy and policy?

\section{The Mechanism of Shakeouts}

Theoretical models of shakeouts have taken two broad approaches. The first approach conceptualizes industry evolution as a shift between equilibria. Firms initially enter and

\footnotetext{
${ }^{1}$ Data in Figure 1 are based on Smith's (1968) List A of automobile manufacturers.

2 Average annual labor productivity growth for rubber manufacturing was 7.8 per cent in 1909-1919, and for tire manufacturing about 9 per cent in 1921-1929, in both cases the most rapid productivity growth of any Census-defined US industry (French 1991, pp. 31 and 52).

${ }^{3}$ Innovations data for automobiles stem from a list of 631 innovations catalogued by Abernathy, Clark and Kantrow (1983); see Klepper and Simons (1997).
} 
populate an industry, reaching an initial-stage equilibrium. Then a major change occurs perhaps new technology becomes available and implies a larger optimal firm size - and firms compete to survive in the ensuing later-stage equilibrium. Some models analyze transitional dynamics in which some firms survive, others exit, and the later-stage equilibrium arises (cf. Jovanovic and MacDonald 1994). Two-equilibrium models tend to be relatively simple to state and analyze, and can characterize basic aspects of industry shakeouts, including the importance of technology innovation and adoption to survival and the advantage of earlier entrants in developing or using technology.

The second approach conceptualizes industry evolution as a continual dynamic process. Entry may occur gradually over time as requisite skills and resources diffuse, but stops not generally when the market equilibrates (which it may never do) but when the growth of entry barriers, perhaps caused by innovation, makes entry unprofitable. Exit likewise may occur gradually, with typical models having a relatively constant probability of exit at all points in time (cf. Klepper 1996; Simons 2006b). Such models have tended to allow relatively rich endogenous decision making about innovation, with larger and more able firms choosing high rates of innovation in order to maximize profit. Continual dynamic models provide an opportunity to describe phenomena, such as the optimal rate of firm growth instead of optimal firm size, that cannot be analyzed in a twoequilibrium model.

Both approaches assume some processes are in equilibrium (markets clear) and some are not (technology changes), but the key difference is whether firm characteristics satisfy a static optimum versus a dynamic optimum. A static optimum implies that, when the equilibrium changes from initial-stage to later-stage, a wave of exit occurs (perhaps preceded by entry) followed by adaptation of surviving firms to the new equilibrium. A dynamic optimum in contrast implies a relatively constant exit rate.

To probe the relevance of these views, consider Figure 1's empirical evidence. The bottom panel of Figure 1 presents a three-year moving average of the percentage of firms that ceased US automobile manufacture in each year. There is no sign of a jump in the probability of exit when the shakeout began in 1909, nor any sign of an equilibration process until at least the late 1920s or, more definitively, the 1940s.

This lack of a jump in exit and of equilibration beginning at the time of the shakeout is typical of industries with shakeouts, and suggests that the continual-dynamic model gives greater insight into shakeouts than the two-equilibrium model. A few industries do have an increase in the probability of exit at the time of the shakeout, but such an increase is rare, may occur in one country but not another country for a given industry, and does not coincide with gradual equilibration of exit rates; in fact exit persists indefinitely (Klepper and Simons 2005; Simons 2006a). Shakeouts result instead when entry decreases. In addition, technological histories of industries with severe shakeouts reveal no exceptional innovations at the times of shakeouts, but instead continual ongoing innovation (Klepper and Simons 1997). The dynamic of exit and innovation is continuous not discrete.

Continual innovation apparently yields the near-cessation of entry. Entry ceases when it becomes unprofitable in the continual dynamic models, which imply rising costs of replicating incumbent firms' rising technological capabilities and productive, managerial and distributive capacities. Profitable establishment of requisite capabilities and assets must occur gradually, because high costs of rapid growth (convex growth 
costs) - documented by numerous empirical studies (Geroski 1995) and a focus of scholars of firm growth (Penrose 1995) - limit firms' expansion.

Continual innovation also yields a steady elimination of the weakest firms. Weaker firms always exist, in the continual dynamic models, given differences in cost and quality caused by differences in innovation. The weakest survivors steadily become unprofitable and exit as industry output grows and prices fall. Differences in cost and quality, far from converging, tend to be amplified because of an endogeneity between firm size and innovation: innovation enhances profitability and hence (optimal) growth and size, and larger firms innovate more because the expense of innovations that enhance quality or reduce average cost can be amortised over a greater number of units sold (cf. Cohen and Klepper 1996). ${ }^{4}$

Hence continual growth and innovation propels a few early entrants to lasting market dominance in industries with shakeouts. Late entrants may attain temporary profitability, but generally exit quickly. Firms with relevant resources at the time of entry most often become dominant in shakeout industries, for which related experience and skilled managers and engineers are associated with greatly enhanced growth and market dominance (Klepper and Simons 2000b; Klepper 2002; Thompson 2007).

\section{Generality and Degree of Shakeouts, Role of Technological Change}

Although shakeouts appear to be widespread (at least among manufactured products), some industries have little or no shakeout, and the timing, rapidity, and degree of shakeouts can vary substantially across industries and nations. Across industries, shakeouts of 20-80 per cent or more (from peak to later low number of firms) are the norm (Gort and Klepper 1982; Klepper and Graddy 1990; Agarwal 1998). Roughly 90 per cent of (highly aggregated) 4-digit SIC level US manufacturing industries from 1963 to 1997 experienced patterns consistent with some part of the shakeout life cycle (Dinlersoz and MacDonald 2006). Across nations, differences in the dynamics of firm numbers may however arise from institutional environments (cf. Nelson 1993; Murmann and Homburg 2001). Nonetheless, the evolution of automobile manufacturer numbers in European nations and in the US has been remarkably similar (Carroll and Hannan 1995), and comparisons of 18 other products between the US and Great Britain reveal tight correlations in the timing and severity of shakeouts (Simons 2005, 2006a).

The degree of shakeout, measured by the eventual percentage drop in firm numbers, is closely tied to the presence of early mover advantage, the dominance of innovation by early entrants and the benefits of innovation for survival (Simons 2006a). Hence technological opportunity for product and process improvement seems, at least in part, to result in shakeouts. In contrast, where measures of marketing budgets and distribution network size have been obtained, they seem to convey more limited or no advantages to firms. Accordingly, these traits do not appear to have been a primary cause of shakeouts in the way product and process technology has been. And while radical technological change sometimes allows late entrants to displace incumbents (Tushman and Anderson

\footnotetext{
4 Considerable innovation continued throughout the histories of the above-mentioned industries with shakeouts, perhaps because internal and exogenous technological developments continued to create new technological opportunity.
} 
1986), such phenomena appear to be rare and have not been associated with shakeouts (cf. Argyres and McGahan, 2002, p. 48).

\section{Implications for Strategy and Policy}

Policy implications of the growing understanding of industry shakeouts depend, in many cases, on policymakers' ability to distinguish a priori whether a budding industry is likely or unlikely to experience a substantial shakeout. This in turn depends on technological and other characteristics of the industry.

A first point is that investment timing matters most for products whose industries experience shakeouts. In these industries, early (but not necessarily first) entrants are sometimes propelled to industry dominance, often benefiting from increasing returns in which size and capabilities allow firms to retain and consolidate their head-start (Philips [1971] makes similar observations regarding the aircraft industry). Late entrants typically exit shortly after entry. By contrast, industries without shakeouts seem to present a more even (and seemingly less risky) set of opportunities, with less advantage to early entry and more opportunity for late entry (Simons 2006a). Investors and potential entrants may make wiser decisions if they can assess underlying conditions that determine whether a shakeout is likely. A caveat is that the relative profitability of industries with and without shakeouts has not been carefully compared. Nonetheless it appears that firms which are able to position themselves in markets where they will be catapulted to advantage are likely to benefit on average.

Second, competition policy has been applied forcefully to the few firms that survive in industry shakeouts, yet ironically these firms are especially likely to end up with concentrated markets even when they act perfectly competitively. ${ }^{5}$ The end result is similar to industries with strong network externalities (Katz and Shapiro 1985), but in this case with the severe discipline of intense technological competition. Nonetheless, the fact that these industries end up concentrated has led some to call for close regulatory scrutiny. Audretsch, Baumol and Burke (2001) introduce some of the implications of industry dynamics for competition policy. ${ }^{6}$

Third, the success of a national or regional economy depends on the success of its firms, so policies that affect firms in industries with shakeouts can have lasting economic impacts. The literature on national economic development has debated the merits of gradual "linear" versus dramatic "leapfrog" development strategies (Hobday 1995; Lu 2000). Support has often been targeted by governments toward particular firms, industries, or technologies. Such aid may work best when the industry is new or lacks the entry barriers associated with shakeouts, and when indigenous firms have comparative advantages such as low labor costs or complementary technological skills. The continual technological change associated with shakeouts fits with the linear development model, but there is evidence that some degree of leapfrogging is possible even in shakeout industries. In rare cases firms and government agencies seem to have used a temporary

\footnotetext{
${ }^{5}$ Some of the relevant antitrust investigations are published as FTC $(1939,1958,1966)$ and MRPC $(1955$, 1968).

${ }^{6}$ What matters most for social welfare is the influence of concentration on technological advance, not price, since new technology (including its embodiment in capital and labor skills) propels most of economic growth. The available evidence suggests that technological advance is greatest when industries are somewhat concentrated but not monopolies (Cohen 1995; Zitzewitz 2003).
} 
conjunction of comparative advantage, short-term protectionism, and spending on innovation to compensate for the lack of early entrant advantages and gain a permanent competitive foothold in such an industry. If such short-term injections of assistance are made (despite the risks), they need to surmount entry barriers if indigenous firms are to challenge existing market leaders and establish dominant capabilities. An example is Japanese firms' use of initially low labor costs, related electronics prowess, and leadingedge use of integrated circuits to dominate the television receiver industry (Wooster 1986).

Fourth, technological innovation seems typically to be the root of success in industries with shakeouts. For firms to survive in this sort of industry, R\&D and engineering require careful management. Rapid expansion to exploit "experience" curves has been suggested by the Boston Consulting Group (1972), but this strategy met with poor results given the difficulty of forecasting future outcomes and the costs associated with expansion (Penrose 1959; Sterman et al. 2006). Moreover the source of the "experience" curve seemingly can be traced to specific changes, notably technological and organizational innovations, that have little to do with output per se or individual employee learning (cf. Sinclair et al. 2000). A better strategy seems to be continual effort to improve product quality and operational and productive efficiency, without attempting to expand more rapidly than optimal absent strategic considerations. Delays in implementing certain types of innovation could harm a firm's market position, as happened to Ford in automobiles when Henry Ford was reticent to implement product changes and was surpassed in market share by General Motors in the late 1920s. Likewise relying on patent protection alone could allow innovative firms to surpass a technological laggard, as tire manufacturers Goodyear and Firestone technologically surpassed the Rubber Goods Manufacturing Company at the start of the 1900s (French 1991, p. 19).

The limiting factor in some of the above suggestions is our ability to discern industries likely to undergo shakeouts versus industries likely to allow continued entry and success of firms. Researchers have not converged on an answer regarding what differentiates these two cases, but Simons (2006a) argues, and provides partial empirical support, that an industry is prone to shakeout when there are large opportunities for product and (perhaps especially) process improvement that cannot effectively be capitalized upon by third-party suppliers. This leads to large numbers of small improvements that are either difficult to protect effectively by patents and other means (since modest changes to a design often allow a firm to get around a patent) or specific to a firm's particular product or manufacturing process. In the context of such dramatic opportunity for in-house innovation, firms must innovate or die.

\section{References}

Abernathy, W. J., Clark, K. B. and Kantrow, A. M. 1983. Industrial Renaissance: Producing a Competitive Future for America, Basic Books, New York.

Agarwal, R. 1998. 'Evolutionary trends of industry variables', International Journal of Industrial Organization, vol. 16, no. 4, pp. 511-525.

Argyres, N. and McGahan, A. M. 2002. 'An interview with Michael Porter', Academy of Management Executive, vol. 16, no. 2, pp. 43-52. 
Audretsch, D. B., Baumol, W. J. and Burke, A. E. 2001 'Competition policy in dynamic markets', International Journal of Industrial Organization, vol. 19, no. 5, pp. 613-634.

Boston Consulting Group. 1972. Perspectives on Experience, Boston Consulting Group, Boston.

Carroll, G. R. and Hannan, M. T. 1995. 'Automobile manufacturers', in Organizations in Industry: Strategy, Structure and Selection, eds G. R. Carroll and M. T. Hannan, Oxford University Press, New York.

Cohen, W. 1995. 'Empirical studies of innovative activity', in Handbook of the Economics of Innovation and Technological Change, Blackwell Publishers, Oxford.

Cohen, W. and Klepper, S. 1996. 'A reprise of size and R\&D', Economic Journal, vol. 106, no. 437, pp. 925-951.

Dinlersoz, E. M. and MacDonald, G. 2006. 'The industry life-cycle of the size distribution of firms', manuscript, University of Houston and Washington University in St. Louis.

Federal Trade Commission (FTC), 1939. Report on the Motor Vehicle Industry, US Government Printing Office, Washington, DC.

Federal Trade Commission (FTC), 1958. Economic Report on Antibiotics Manufacture, US Government Printing Office, Washington, DC.

Federal Trade Commission (FTC), 1966. Economic Report on the Manufacture and Distribution of Automotive Tires, US Government Printing Office, Washington, DC.

French, M. J. 1991. The U.S. Tire Industry, Twayne Publishers, Boston.

Geroski, P. A. 1995. 'What do we know about entry?', International Journal of Industrial Organization, vol. 13, no. 4, pp. 421-440.

Gort, M. and Klepper, S. 1982. 'Time paths in the diffusion of product innovations', Economic Journal, vol. 92, no. 367, pp. 630-653.

Hobday, M. 1995. Innovation in East Asia: The Challenge to Japan, Edward Elgar, Cheltenham.

Jovanovic, B. and MacDonald, G. 1994. 'The life cycle of a competitive industry', Journal of Political Economy, vol. 102, no. 2, pp. 322-347.

Katz, M. L. and Shapiro, C. 1985. 'Network externalities, competition, and compatibility', American Economic Review, vol. 75, no. 3, pp. 424-440.

Klepper, S. 1996. 'Entry, exit, growth, and innovation over the product life cycle', American Economic Review, vol. 86, no. 3, pp. 562-583.

Klepper, S. 2002. 'Firm survival and the evolution of oligopoly', RAND Journal of Economics, vol. 33, no. 1, pp. 37-61.

Klepper, S. and Graddy, E. 1990. 'The evolution of new industries and the determinants of market structure', RAND Journal of Economics, vol. 21, no. 1, pp. 27-44.

Klepper, S. and Simons, K. L. 1997. 'Technological extinctions of industrial firms: An enquiry into their nature and causes', Industrial and Corporate Change, vol. 6, no. 2, pp. 379-460.

Klepper, S. and Simons, K. L. 2000a. 'The making of an oligopoly: Firm survival and technological change in the evolution of the U.S. tire industry', Journal of Political Economy, vol. 108, no. 4, pp. 728-760.

Klepper, S. and Simons, K. L. 2000b. 'Dominance by birthright: Entry of prior radio producers and competitive ramifications in the U.S. television receiver industry', Strategic Management Journal, vol. 21, no. 10-11, pp. 997-1016. 
Klepper, S. and Simons, K. L. 2005. 'Industry shakeouts and technological change', International Journal of Industrial Organization, vol. 23, no. 1-2, pp. 23-43.

Lu, Q. 2000. China's Leap into the Information Age: Innovation and Organization in the Computer Industry, Oxford University Press, Oxford.

Monopolies Commission (MRPC). 1968. Second Report on the Supply of Electric Lamps, Her Majesty's Stationery Office, London.

Monopolies and Restrictive Practices Commission (MRPC). 1955. Report on the Supply and Export of Pneumatic Tyres, Her Majesty's Stationery Office, London.

Murmann, J. P. and Homburg, E. 2001. 'Comparing evolutionary dynamics across different national settings: The case of the synthetic dye industry, 1857-1914', Journal of Evolutionary Economics, vol. 11, no. 2, pp. 177-205.

Nelson, R. R., ed. 1993. National Innovation Systems: A Comparative Analysis, Oxford University Press, New York.

Penrose, E. 1959. The Theory of the Growth of the Firm, John Wiley \& Sons, New York. Phillips, A. 1971. Technology and Market Structure: A Study of the Aircraft Industry, D.C. Heath and Company, Lexington, Mass.

Simons, K. L. 2005. 'Predictable cross-industry heterogeneity in industry dynamics," in Essays in Honor of Edwin Mansfield: The Economics of $R \& D$, Innovation and Technological Change, eds A. N. Link and F. M. Scherer, Springer, New York.

Simons, K. L. 2006a. 'Product market characteristics and the industry life cycle', manuscript, Rensselaer Polytechnic Institute.

Simons, K. L. 2006b. 'On the theory of product market characteristics and the industry life cycle', manuscript, Rensselaer Polytechnic Institute.

Sinclair, G., Klepper, S. and Cohen, W. 2000. 'What's experience got to do with it? Sources of cost reduction in a large specialty chemicals producer', Management Science, vol. 46, no. 1, pp. 28-45.

Smith, P. H. 1968. Wheels within Wheels: A Short History of American Motor Car Manufacturing, Funk and Wagnalls, New York.

Sterman, J. D., Henderson, R., Beinhocker, E. D. and Newman, L. I. 2006. 'Getting big too fast: Strategic dynamics with increasing returns and bounded rationality', MIT Sloan working paper 4595-06.

Thompson, P. 2007. 'Founder quality and firm performance: Implications for local development strategies', Australian Economic Review, vol. 40, no. 1, pp. XXXX.

Tushman, M. L. and Anderson, P. 1986. 'Technological discontinuities and organizational environments', Administrative Science Quarterly, vol. 31, no. 3, pp. 439465.

Wooster, J. H. 1986. 'Industrial policy and international competitiveness: A case study of U.S. - Japanese competition in the television receiver manufacturing industry', $\mathrm{PhD}$ thesis, University of Massachusetts.

Zitzewitz, E. W. 2003. 'Competition and long-run productivity growth in the UK and US tobacco industries, 1879-1939', Journal of Industrial Economics, vol. 51, no. 1, pp. 133. 
Figure 1 US Automobile Manufacturers

Firms, Entry and Exit

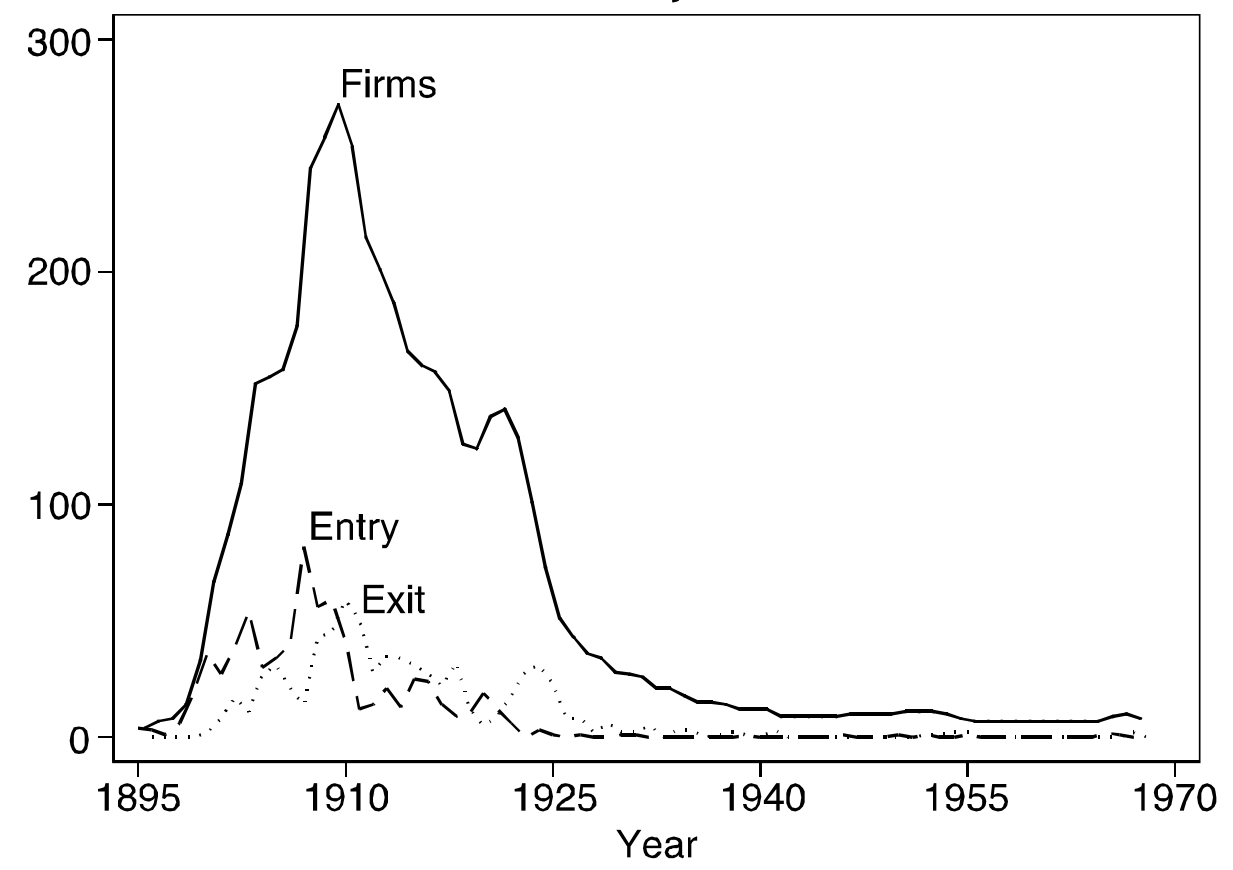

Percentage Exit (3-year moving average)

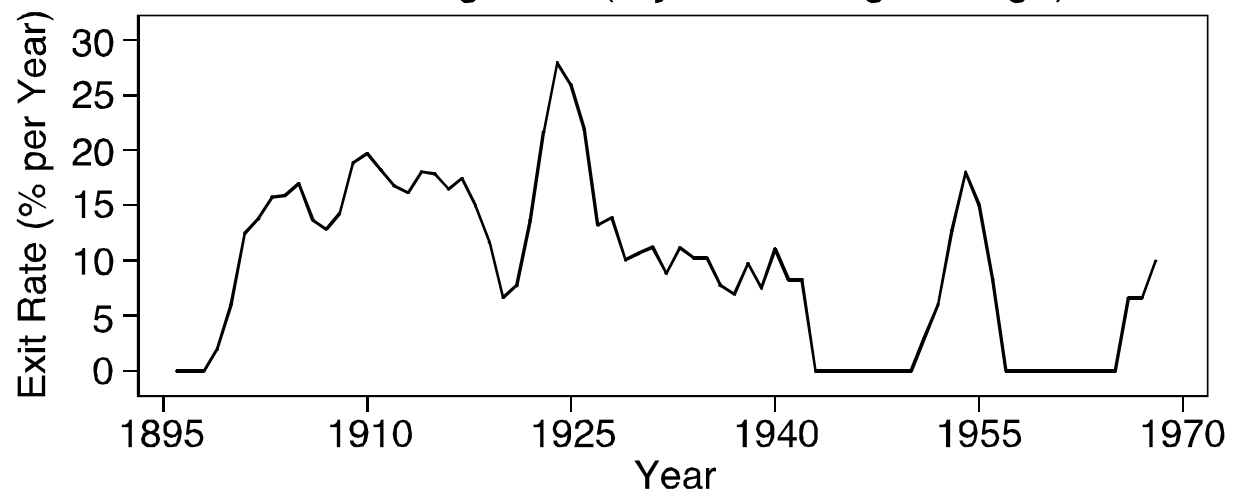

